Novikova Olha, Senior Lecturer of the Department of Economics and Entrepreneurship, Sumy National Agrarian University, Sumy, Ukraine

ORCID ID: 0000-0002-6999-9268

e-mail: novikova.css@gmail.com

Zhang Kuan, Student of the Master's course, Sumy National Agrarian University, Sumy, Ukraine

ORCID ID: 0000-0002-3992-0838

e-mail: ethanzhang366@gmail.com

\title{
Analyses of the E-Commerce Development in the World and China
}

\begin{abstract}
With the development of economic globalization, people's lives have undergone earth-shaking changes. The so-called economic globalization refers to the continuous development of production, accelerating technological progress, and the continuing improvement of the socialization and internationalization of production. The business activities of countries and regions in the world are increasingly beyond the scope of a country and region accompanied by the integration process of connection and interdependence. E-commerce is a small development that offered a brand-new transaction method that uses an electronic paperless method for operations. With the continuous development of information technology and the increasing prosperity of global economic activities, e-commerce has played a vital role in the national economy.

Purpose. The main stages of e-commerce development in the world and China are summarized in this article together with the positive and negative effects of globalization on e-commerce. Under the influence of globalization, e-commerce has different characteristics and orientations. This article mainly focuses on the pros and cons of e-commerce, the general stages of its development in the world, and China, directions, and conditions for upcoming growth.

Results. For e-commerce, now is the time for vigorous development. Therefore, it is necessary to improve and develop some national strategies for electronic trading methods. The future development of e-commerce depends on strategy and the legal system. First, we need to accelerate the construction of information networks, seek quality and standardization in development, and build a reliable information development platform that satisfies the individual needs of all members of the society. Secondly, it is needed to improve the legal system for online trade and take active measures to encourage and support more traditional enterprises and relocating their products and services to online selling platforms. National authorities should strengthen planning and guidance to ensure the healthy and stable development of e-commerce.

Conclusions. Globalized economic activities have brought a broader market to e-commerce, but it still has the potential for future growth. For future business development, it is needed to control the integration processes and improve the system to make it better to serve the public.
\end{abstract}

Keywords: e-commerce; globalization; economic growth; e-trade; B2B; B2C; stages of e-commerce development.

\section{УДК 339.926}

Новікова О. С., старший викладач кафедри економіки та підприємництва, Сумський національний аграрний університет, м. Суми, Україна Україна

Чжан Куан, студент магістерського курсу, Сумський національний аграрний університет, м. Суми,

\section{Аналіз розвитку електронної комерції в світі та КНР}

Анотація. Розвиток економічної глобалізації призвів до стрімкого зростання внутрішньої та міжнародної торгівлі. Економічна глобалізація при цьому розглядається в контексті безперервного вдосконалення виробництва, пришвидшеного технологічного прогресу та безперервного покращення соціалізації та інтернаціоналізації економіки. Економічна активність країн та регіонів світу швидко виходить за свої географічні межі $і$ супроводжується інтеграційними процесами взаємопов'язаності та взаємозалежності. Електронна комерція сама по собі не $\epsilon$ унікальною технологією, вона являє собою новітній метод виконання транзакцій без використання паперу шляхом комунікацій через інтернет чи інші мережі цифрової передачі даних. Завдяки постійному розвитку інформаційних технологій та дедалі більшому обсягу світової торгівлі електронна комерція стала відігравати ключову роль $в$ економічному зростанні КНР. Під впливом глобалізації електронна комерція набула специфічних рис та напрямів розвитку. Глобалізація мала різний вплив на процеси електронної торгівлі, але глобальний економічний розвиток завжди залишався основним ї̈ рушієм і суттєво вплинув на всі аспекти людського життя. У статті досліджуються всі етапи розвитку електронної торгівлі яку світі, так і окремо - в КНР, особлива увага приділена окремим тенденціям їі розвитку останніми роками на етапі зрілості, коли завдяки процесам інтеграції та консолідації капіталів кілька платформ для онлайн торгівлі посіли провідне місце у світі за обсягами продажів. У дослідженні виокремлено основні переваги та недоліки такого виду торгівлі. Енергійний розвиток електронної комерції на сучасному етапі обумовлює необхідність вдосконалити та розробити деякі національні стратегії та правову систему. По-перше, пришвидшити

Стаття надійшла до редакції: 18.10 .2020

Received: 18 October 2020 
побудову базових інформаційних мереж, домагатися якості та стандартизації у розвитку та побудувати платформу інформаційного розвитку, яка задовольняє суспільство. По-друге, вдосконалити правову систему торгівлі в Інтернеті. Необхідно вживати активних заходів для заохочення та підтримки традиційних підприємств та сприяти продажу їхньої продукції та послуг через інтернет.

Ключові слова: електронна комерція; глобалізація; економічне зростання; електронна торгівля; В2B; B2C; стадії розвитку електронної комерції.

Formulation of the problem. E-commerce emerged in the nineties and has quickly become the most dynamic sphere of exchange facilitating the steady increase of the Chinese economy together with other countries. They managed to utilize its economic potential and achieve perfect results of international trade both in $\mathrm{B} 2 \mathrm{~B}$ and $\mathrm{B} 2 \mathrm{C}$. Innovative business models have transformed market relationships and pushed out the frontier of online sales. In this paper, general trends and important stages of ecommerce development will be summarized.

Analysis of recent research and publications. The topical issue of e-commerce development has been thoroughly examined by the most outstanding economists in the world. Schafer and Rayport [10] have been analyzing the most primary stages of the origin of the phenomenon. Further development was described in detail by Peng Fei [8]. In this article, these ideas we used as a basis for forecasting that supported with recent statistics to make predictions for future development.

Formulation of research goals. Thus, the purpose of the article is to outline basic trends in e-commerce development, define key features of different stages and strategies for benefiting from participation in e-commerce together with primary benefits and drawbacks of ecommerce growth for the economy.

Outline of the main research material. The concept itself refers to a business model centered on commodity exchanges using information network technology; it includes the activities with transactions conducted and related to services in the form of electronic operations on the Internet, corporate intranets, and value-added networks; all in all, according to [2] most commercial activities provided using the Internet as a medium belongs to the category of e-commerce.

E-commerce usually refers to a wide range of commercial trade activities all over the world, in the open network environment of the Internet, based on client/server application methods, buyers and sellers conduct various business activities without meeting each other to facilitate consumers' online shopping, an alternative type of business operating model for online transactions and online electronic payments between merchants[3], as well as various business activities, transaction activities, financial activities and related comprehensive service activities.

Stages of global e-commerce development were summarized $[4,6,9]$ and the following are being listed below:

The first stage: Email stage. This stage appeared with the introduction of digital means of communication in the 1970s, since then the average communication volume had increased by several times within a few years.

Second stage: Information release stage. Since 1995, the information publishing system represented by Web technology has grown explosively and has become the main application of the Internet. SMEs would shift the ecommerce from "extensive" to "precise" marketing era.

The third stage: EC (Electronic Commerce), the ecommerce stage itself. EC has modified the economy of the United States. The reason why EC was listed as an epoch-making phenomenon is that the ultimate commercial use of the Internet is e-commerce. At the same time, we could safely conclude that the business information after a few years was mainly transmitted through the Internet. The Internet was about to become the nervous system of our business information society. At the Fifth APEC Informal Summit (APEC) held in Vancouver, Canada at the end of 1997, US President Clinton appeared with a proposal to urge all countries to jointly promote the development of e-commerce, which attracted the attention of global industry leaders, such as IBM, HP, and Sun. Vendors of information technology have declared 1998 to be the year of e-commerce.

Fourth stage: The entire e-commerce stage. With the emergence of the SaaS (Software as a Service) software service model, the software has logged on to the Internet, extending the e-commerce chain and forming the latest "full e-commerce" conceptual model.

Fifth stage: Wisdom stage. In 2011, Internet information fragmentation and cloud computing technology became more and more mature, and that was when an active Internet marketing model appeared. ICommerce (individual Commerce) took advantage of the trend. It moved to the Internet, having got rid of the traditional sales model. In-depth communication with users from multiple perspectives such as user care. Among them, ICE proposed by IZP Technology Group is the most representative.

These processes, although started later, are strongly connected with similar trends happening in China which you are presented in Table 1 below. Researchers have also separated China's e-commerce development into phases. Based on the development of the main e-commerce platforms in China, Wang Y., Shen $H$ [11] outlined six stages: germination, growth, accelerate, mature, outbreak, and transformation but the last two still could be summarized within the stage of maturity. We've connected them to the basic events in state regulation in tabl.1. 
Електронне наукове фахове видання з економічних наук “Modern Economics», №23 (2020), 155-160 https://modecon.mnau.edu.ua | ISSN 2521-6392

Table 1. The main historical stages of e-commerce development in China

\begin{tabular}{|c|c|}
\hline \multicolumn{2}{|r|}{ Initial stage } \\
\hline 1990-1993 & The era of electronic data workflow has become the beginning of China's e-commerce \\
\hline \multicolumn{2}{|r|}{ Preliminary stage } \\
\hline 1993-1997 & $\begin{array}{l}\text { The government led the way to carry out the "Three Golden Project" stage, laying a solid foundation for the } \\
\text { development of e-commerce }\end{array}$ \\
\hline 1996 & $\begin{array}{l}\text { The State Council's National Informatization Work Leading Group was established and headed by the Vice } \\
\text { Premier with the active participation of more than } 20 \text { ministries and commissions to lead and organize China's } \\
\text { informatization construction }\end{array}$ \\
\hline 1996 & Jinqiao Network and the Internet were officially introduced to common usage \\
\hline 1997 & $\begin{array}{l}\text { The Information Office organized relevant departments to draft and prepare China's informatization plan, } \\
\text { advertisers began to use online advertising; China Goods Order System (CGOS) began to operate }\end{array}$ \\
\hline \multicolumn{2}{|r|}{ Development period } \\
\hline $1998-2000$ & $\begin{array}{l}\text { During the development stage of Internet e-commerce, China's first Internet transactions were successfully } \\
\text { performed }\end{array}$ \\
\hline 1998 & $\begin{array}{l}\text { The State Economic and Trade Commission and the Ministry of Information Industry jointly announced the } \\
\text { launch of a project with electronic trade as the main content }\end{array}$ \\
\hline 1999 & $\begin{array}{l}\text { B2C websites such as } 8848 \text { were officially opened, and online shopping has entered the practical application } \\
\text { stage }\end{array}$ \\
\hline \multicolumn{2}{|r|}{ Stable growth stage } \\
\hline $2000-2009$ & $\begin{array}{l}\text { E-commerce has gradually become the main body of traditional industry B2B, marking that e-commerce has } \\
\text { entered a stable period of sustainable development }\end{array}$ \\
\hline \multicolumn{2}{|r|}{ Mature stage } \\
\hline $2009-\ldots$ & E-commerce has been valued by national senior officials and has been elevated to the national strategic level \\
\hline
\end{tabular}

Source: summarized by author based on [6,7]

Starting from 2010 China's e-commerce has entered the stage of maturity, which can be characterized by stable economic growth, rigid features of separate subdivisions, careful strategic planning. The Government of China has played a key role in the process of growth and development by creating an environment for e-commerce to progress and putting in place regulations and policies to support this sphere, which accompanied its growth. Since that time it continued to flourish, which is supported by recent statistical data, presented in fig. 1 .

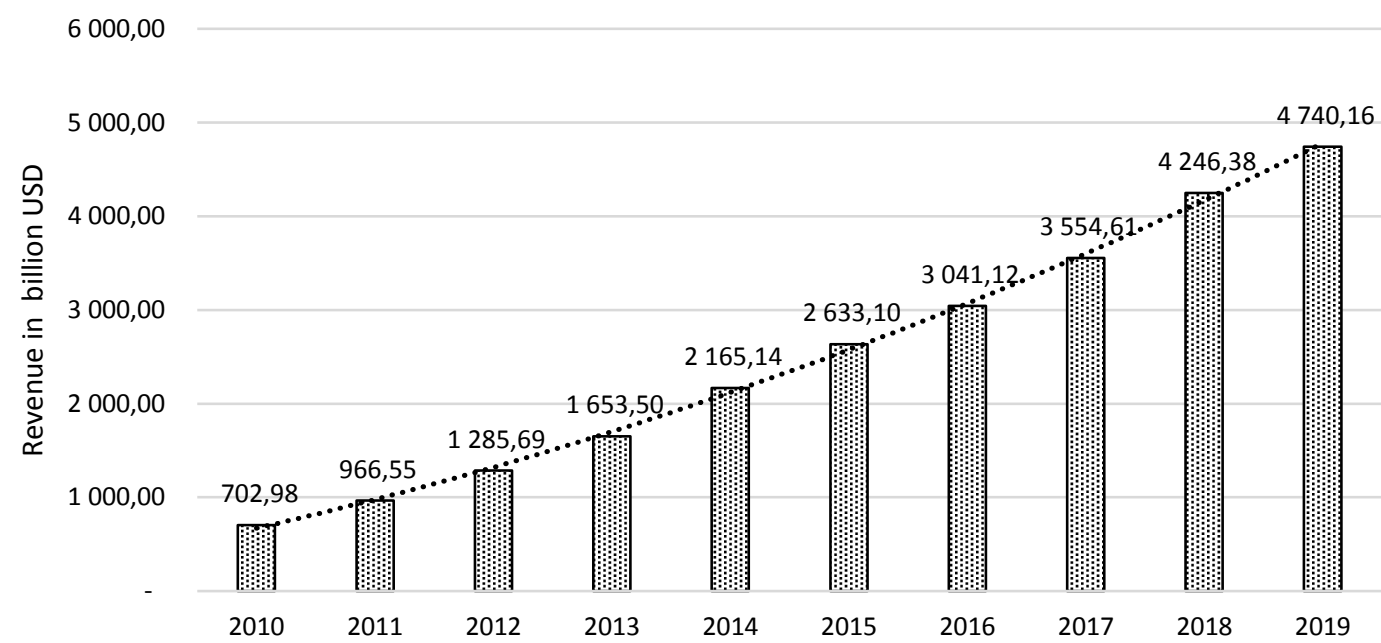

Figure 1 - Gross merchandise volume of China's e-commerce market in 2010-2019

Source: summarized by author based on [12]

According to the information presented in the chart 1, the gross merchandise value, which is the total value of merchandise sold through customer-to-customer distribution channels, has grown from 702.98 billion dollars in 2010 up to 4740.16 billion dollars in 2019. The average yearly growth rate was $23,91 \%$, this number indicates e-commerce has good marketing, and it also proves the strong positions of China on the global market.

China's B2B e-commerce has shown a strong growth trend from 2012 to 2017, while the market size was rapidly growing, which is illustrated in fig. 2 . 


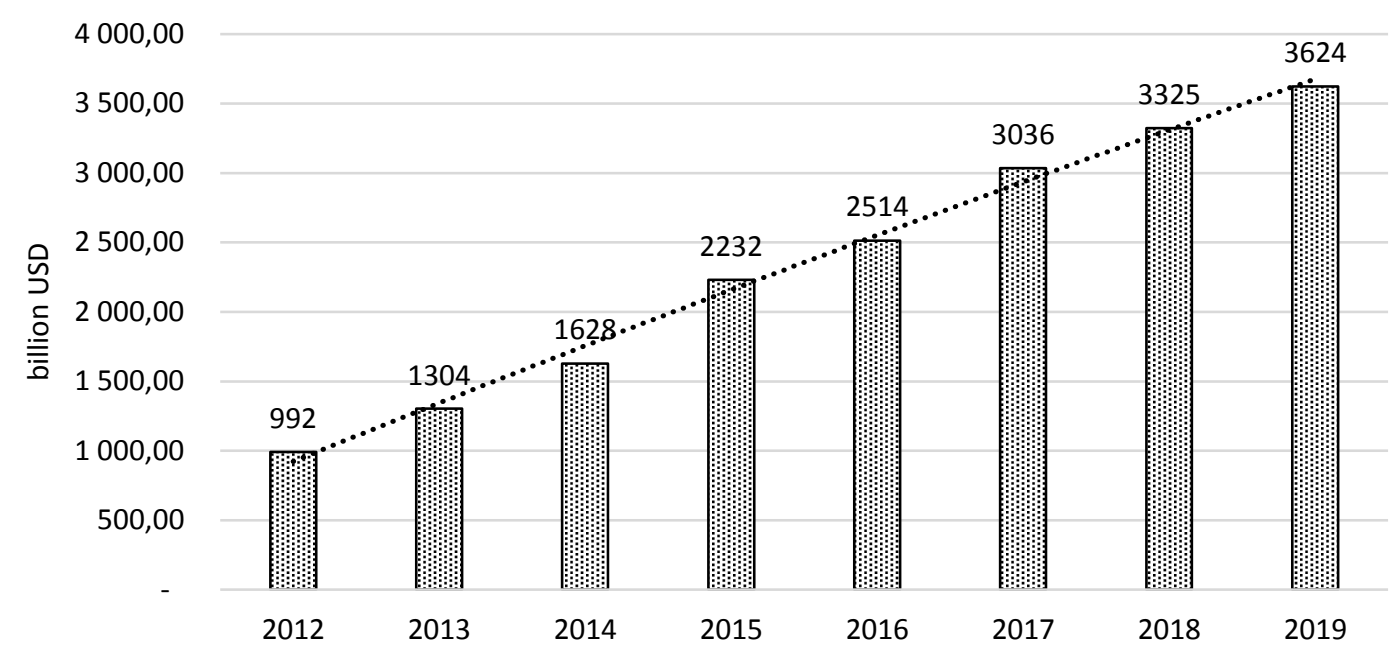

Figure 2 - The transaction volume of B2B e-commerce in China 2012-2019

Source: summarized by author based on [13, 16]

The transaction volume of $\mathrm{B} 2 \mathrm{~B}$ commerce presented in Chart 2 shows that the scale of the B2B market in the Chinese market has grown from 922.05 billion dollars in 2012 to 3624 billion dollars in 2019, with an average annual growth rate of $25,4 \%$. Through the trend line, we can find that the growth trend will continue, which shows that China's B2B e-commerce has matured.

The data shows that China's B2B transactions are mainly conducted through several platforms, as shown in fig. 3.

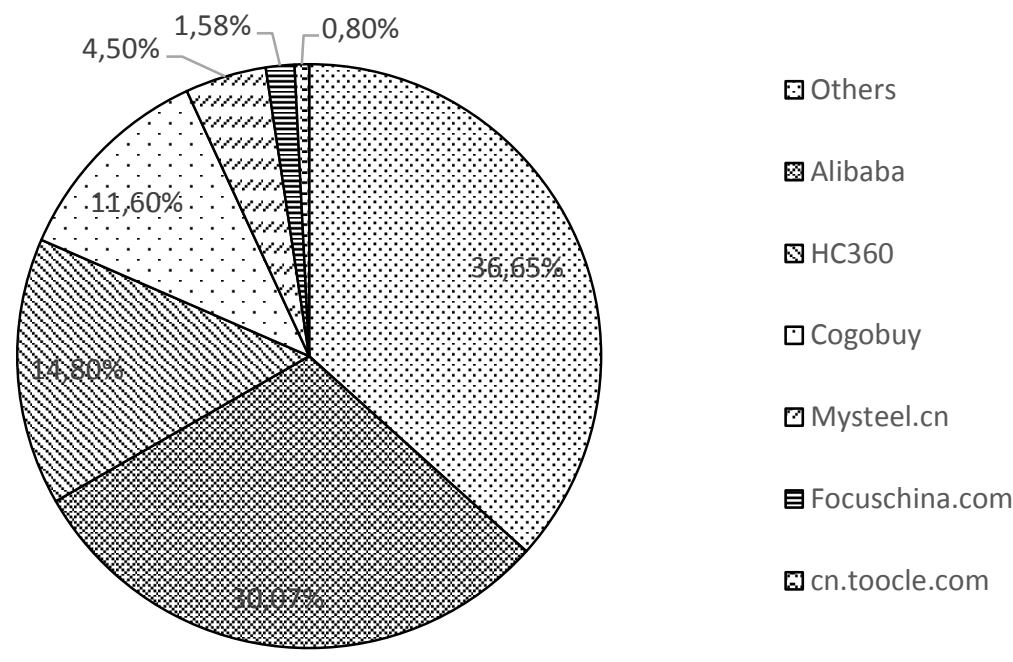

Figure 3 - B2B online platforms' market share in China in 2018

Source: author's research based on [14]

As we can find in Chart 3 in the B2B e-commerce market share Alibaba can be considered to be the market leader, followed by the HC360 platform. These two platforms account for more than $40 \%$ of the market share, but it can also be seen that other platforms are also actively participating, which shows that China's B2B ecommerce shows a trend of common development, which is more conducive to the healthy development of China's e-commerce
As an important branch in the modern service industry, e-commerce not only has the characteristics of high technology content, high human capital, and added value, but also has significant features including new technologies, new formats, and new methods. On the whole, the development of global e-commerce is showing a trend of rapid growth. According to data released by the Statista [16] total global online retail transaction volume in 2019 amounted to 3.53 trillion U.S. dollars and e-retail revenues are expected to grow to 6.54 trillion US dollars 
in 2022 with a growth speed higher, than the general retail trade increase. The U.S. Department of Commerce reports that e-commerce as a percent of all retail sales increased from $11.8 \%$ in the first quarter of 2020 to $16.1 \%$ in the second quarter, representing a $31.8 \%$ increase to $\$ 211.5$ billion. In 2014, a survey of online purchase intentions showed that global netizens' online purchase intentions doubled in three years. Among them, online browsing in Latin America is the highest in the world, and online shopping is the highest in the Asia-Pacific region.

It can be concluded that global e-commerce has several trends in development:

Regionalization trend: Looking at the global ecommerce market, the development of various regions is not balanced. As the first country to develop e-commerce, the United States has naturally become the most mature country for e-commerce development. Many e-commerce trends started in the United States and gradually became popular around the world; although Europe and other countries started later than the United States, however, under the active promotion of the European Union, the development speed of e-commerce has been maintained at a relatively fast level of development; Asia is represented by China, and it has been a market with huge potential since the beginning of the development of ecommerce. Compared with other parts of the world, the share is not ideal.

Integration trend: As the results of the analysis and research on the development of e-commerce in recent years show, global Internet companies are currently in a stage of cooperation, mergers, and reorganizations based on the Internet, relying on the industry and taking the value chain as the core[6]. The mergers between similar websites will continue. For example, Dangdang entered Taobao Mall, Alibaba integrated Meituan, etc. These mergers and acquisitions have almost the same website positioning, and the consumer products they can provide are similar to the corresponding consumer groups in a certain sense. Therefore, the merger and reorganization between them can reduce competitors in the same market, diminish waste of resources, and jointly improve competitiveness. Different websites will complement and improve each other. The advantages and disadvantages of each e-commerce company are different, which encourages many websites with different sales profiles to be merged, making full use of their respective resources, customer sources, and other complementary advantages to reduce shortcomings.

Mobile trend: In 2018, global e-commerce reached 2.47 trillion U.S. dollars. Thanks to mobile internet, more and more consumers can easily purchase and provide payment through mobile devices. The application of mobile devices has increased the use of e-banking and epayment, which has stimulated the development of ecommerce to a large extent and also provided consumers with the possibility to purchase more goods and services
[10]. On the day of Double Eleven in 2019, mobile Taobao single-day active users more than US\$500 million, It also created a turnover of 14.5 billion US dollars 1 hour after the opening. In the end, the transaction amount on this day was a record of US $\$ 38.9$ billion, an increase of $20.8 \%$ over the US $\$ 32.2$ billion in 2018. These data indicate ecommerce is in the midst of a new period of explosive entrepreneurial activity focusing on on-demand services, social networks, and the mobile platform created by smartphones and tablet computers.

Diversification trend: E-commerce is experiencing an effect of diversified payment methods. As early as 1998, Peter Thiel and Max Levchin established Paypal, the world's largest online payment company. In the beginning, it was mainly an account type designed for users with international payment needs [16]. In 2019, PayPal platform transaction volume reached US\$711.9 billion (2012-19 CAGR 25\%), operating income reached US\$17.8 billion (CAGR 18\%), and non-GAAP net profit reached US\$37 billion (CAGR 21\%) [17]. This shows that mobile payment has become an important part of ecommerce. There are a variety of options in the development of electronic payment today. We can choose Paypal, cross-border Visa cards, cryptocurrency, many international websites that can use Alipay designed by Taobao to implement cross-border payment functions.

For e-commerce, now is the time for vigorous development. Therefore, it is necessary to improve and develop some national strategies for electronic methods. The future development of e-commerce depends on strategy and the legal system. Firstly, we need to speed up the construction of basic information networks, seek quality and standardization in development, and build an information development platform that satisfies the growing needs of society. Secondly, it is needed to improve the legal system for online trade and take active measures to encourage and support more traditional enterprises and the electronification of their products and services trade activities. National authorities should strengthen planning and guidance to ensure the healthy and stable development of e-commerce.

Conclusion. Having classified between four general trends in e-commerce development we can conclude that despite rapid growth in the last 30 years there is still a potential for future increase. Despite globalization, its development has strong regional features with strong market positions of the American companies as pioneers of e-commerce which were subsequently outpaced by the platforms from China. Due to strong government support and integration, they managed to obtain 4740,16 billion of gross merchandise volume in 2019 with a concentration rate of $66 \%$ of the market occupied by the two biggest platforms. With a recent mobile trend and diversification of the methods of payment, it is projected to continue growing at double-digit rates over the next five years, remaining the fastest growing form of commerce. 


\section{References:}

1. Canzer, B. (2006). E-Business: Strategic Thinking and Practice. Cengage Learning. 347p.

2. Falchuk, B., \& Jayaraman, V. (2006). Online Multimedia E-Commerce. Encyclopedia of Multimedia, 662-671. doi:10.1007/0-387-300384_180.

3. Jing Zhao (2016). An exploratory study on business-to-consumer electronic commerce in China. University as a Bridge from Technology to Society. IEEE International Symposium on Technology and Society (Cat. No.00CH37043). doi:10.1109/istas.2000.915632.

4. Laudon, K. and Traver, C. (2008). History of e-commerce. E-Commerce: Business, Technology, Society, 4th Edition, Prentice Hall, pp.48-67.

5. Laudon, K. C., \& Traver, C. G. (2016). E-commerce: business, technology, society. Retrieved from http://repository.fue.edu.eg/xmlui/bitstream/handle/123456789/4464/10986.pdf?sequence=1\&isAllowed=y.

6. Liang Shuling (2019). Discussion on the status quo and development of B2B e-commerce standardization in China. China Standardization, 10, 14-26. [In Chinese].

7. Liu Peinan (2014). Exploring research on e-commerce and traditional commerce [J]. Technology and Innovation, (19), 76-89 [in Chinese].

8. Peng Fei (2017). The research status and development trend of B2B e-commerce model in developing countries [J]. Financial Economy, 4, 34-39 [in Chinese].

9. Rayport, J. F. \& Jaworski, B. J. (2003). Introduction to e-commerce. McGraw-Hill, Inc.

10. Schafer, J. B., Konstan, J. \& Riedi, J. (1999). Recommender systems in e-commerce. Proceedings of the 1st ACM Conference on Electronic Commerce - EC'99. doi:10.1145/336992.337035.

11. Wang, Y., Shen, H. \& Pu, G. (2020). Application of Big Data in B2C E-commerce Market Analysis. Big Data Analytics for Cyber-Physical System in Smart City, 870-876. doi:10.1007/978-981-15-2568-1_118.

12. Yihan Ma (2020). China's E-commerce Market Data Monitoring Report. Retrieved from https://www.statista.com/statistics/1129543/ china-e-commerce-market-gross-merchandise-volume/.

13. Yihan Ma (2020). China's E-commerce Market Data Monitoring Report. Retrieved from https://www.statista.com/statistics/302040/ transaction-volume-of-b2b-e-commerce-china/.

14. Yihan Ma (2020). China's E-commerce Market Data Monitoring Report. Retrieved from https://www.statista.com/statistics/243845/ market-share-of-b2b-online-retailers-in-china/.

15. Zhang Jun (2017). Overview of China's e-commerce forecasting problems. Accounting Research, (3) [in Chinese].

16. Zheng, Q., Han, Y., Li, S., Dong, J., Yan, L. \& Qin, J. (2009). Payment Technologies for E-commerce. Introduction to E-Commerce, 115134. doi:10.1007/978-3-540-49645-8_3.

17. Statista. Global Business Data platform. Retrieved from https://www.statista.com/markets/

Ця робота ліцензована Creative Commons Attribution 4.0 International License 